\title{
EFFECT OF BIOFERTILISER CONTAINING DIFFERENT PERCENTAGE RATES OF CHEMICAL FERTILISER ON OIL PALM SEEDLINGS
}

\author{
NURHAFIZHOH ZAINUDDIN*; MOHD FAHMI KENI* and SHARIFAH AZURA SYED IBRAHIM*
}

\begin{abstract}
Extensive use of inorganic substances contained in chemical fertilisers leads to environmental pollution and makes the plant more susceptible to diseases. The utilisation of beneficial microbes in biofertilisers has become a key solution in reducing the usage amount of chemical fertilisers in agriculture. This study was conducted on oil palm seedlings (OPS) in a nursery and treated with biofertiliser with zero chemicals (BF0), biofertiliser containing two percentage levels of chemical fertiliser (CF) $(B F+40 \% C F$ and $B F+50 \% C F)$ and two controls consisting of 100\% chemical (CF100) and standard organic (SO) fertiliser. The vegetative measurements and foliar nutrients analysis for the OPS were recorded three and five months after fertilisation (MAF), when the OPS were six and eight months old, respectively. The application of biofertilisers containing low CF rates resulted in higher vegetative measurements compared to application of 100\% chemical. Nutrients analysis showed that application of biofertiliser assisted in the increase of essential nutrients uptake in the OPS. Thus, we concluded that combination of biofertiliser with small rates of chemical able to increase vegetative measurements and nutrients uptake. Biofertiliser application is also capable in reducing the sole use of 100\% chemical fertilisers, which is not environmental-friendly and expensive.
\end{abstract}

Keywords: biofertiliser, chemical fertiliser, vegetative measurements, nutrients uptake.

Date received: 5 February 2019; Sent for revision: 18 February 2019; Received in final form: 13 May 2019; Accepted: 24 October 2019.

\section{INTRODUCTION}

For optimum plant growth, nutrients must be supplied sufficiently and are in balanced quantities (Chen, 2006). Intensive farming practices, that demand high yield and quality, require the extensive use of chemical fertilisers. However, the most important constraint that limit the plant growth is soil fertility (Mohammadi and Sohrabi, 2012). Due to the extensive use of chemical fertilisers, which are not environmental-friendly, has resulted in many environmental problems such as soil acidification, greenhouse gases emission and destruction of friendly microorganisms which reduce the soil

\footnotetext{
Malaysian Palm Oil Board, 6 Persiaran Institusi,

Bandar Baru Bangi, 43000 Kajang,

Selangor, Malaysia.

E-mail: nurhafizhoh@mpob.gov.my
}

fertility due to the excessive nutrients, heavy metals and high concentration of radionuclides (Savci, 2012; Zhao et al., 2016). Apart from that, sole application of chemical fertilisers has also displayed the disadvantages such as leaching and polluting water basins making the plants more susceptible to the attack of diseases and causing irreparable damage to the overall biological system (Ibiene et al., 2012).

Researchers started to introduce beneficial microbes in inorganic fertilisers as the microbes are effective in promoting plant growth by secreting out plant growth promoters such as auxins (Zahir et al., 2010). Biofertilisers which contain bacteria inoculants help to reduce environmental problems by maintaining many kinds of important nutrients in the soil via nitrogen fixation, phosphate and potassium solubilisation, release of plant growth 
promoter and biodegradation of organic matters in soil (Bhardwaj et al., 2014).

Plant requires optimum supply of nutrients to enhance its growth and yield. The deficiency of important nutrients can adversely affect plant growth and performance (Miransari, 2013). Unlike chemical fertilisers which are not environmentalfriendly, biofertilisers which contain different types of microorganisms, have become an essential component to sustain the oil palm growth by enhancing the nutrients uptakes (Mishra et al., 2013). Inoculants containing beneficial microbes applied in fertilisers are responsible in supplying adequate nutrients to the plant and increase plant growth (Egamberdiyeva, 2007).

Nowadays, studies to reduce the usage of inorganic fertilisers have received great attention by researchers. Successful nutrient management in biofertilisers can provide sustainable yields and become an alternative to replace the usage of $100 \%$ chemical fertilisers. Essential nutrients such as nitrogen, phosphorus and potassium must be present in biofertilisers for uptake by roots (Munda et al., 2015). Organism that are commonly used as biofertilisers component are nitrogen fixers (N-fixer), potassium solubiliser (K-solubiliser) and phosphorus solubiliser (P-solubiliser), or with the combination of fungi. Most of the microbes included in biofertiliser have closed relationship with plant roots (Mohammadi and Sohrabi, 2012). Apart from that, Gupta (2004) stated that microorganism contained in biofertilisers mainly bacteria and fungi possess the ability to make insoluble $\mathrm{P}$ available to the plants and to bring insoluble phosphate into soluble forms.

The sole application of chemical fertilisers has led to a decline in soil fertility (Savci, 2012). Thus, researchers agreed that biofertiliser application with the integration of small amounts of chemical fertilisers can maintain and increase the soil fertility while enhancing the plant development (Mekki, 2016). Mondal et al. (2015) studied the impact of reduced dose of chemical fertiliser (CF) with its combination with biofertiliser of mustard (Brassica campestris cv. $\mathrm{B}_{9}$ ). The fertiliser was formulated using a full recommended dose of CF (N:P:K-100:50:50) combined with biofertiliser. Apart from that, a study on application of organic fertiliser in combination with CF (N:P:K-15:15:15) also indicated significant effect on the growth of kenaf (Hibiscus cannabinus L.) (Hadi et al., 2013). Therefore, this study was conducted to determine the effects of biofertilisers as well as to compare the effects of biofertiliser containing different rates of CF with the application of $100 \%$ chemical (CF100) and standard organic (SO) fertilisers on vegetative measurements and nutrients uptake of oil palm seedlings (OPS) after three and five months of fertiliser application.

\section{MATERIALS AND METHODS}

\section{Preparation of Inoculum and Biofertiliser Formulation}

Seventeen different kinds of microorganisms from several classes of bacteria and fungi were utilised in the production of biofertiliser in this research. The microbes were chosen in this formulation based on their capability to promote plant growth. The consortium of microbes consisted of five microbes from prokaryotes of group Proteobacteria; two bacteria were from the genus Bacillus and the other three bacteria were from the genera of Providencia, Phyllobacterium and Sphingobacterium. Fungi consisted of three species of Trichoderma and one species each of Antrodia, Pichia, Pycnoporus and Phanerochaete. Generally, these microbes were protected under Malaysia Patent No. PI 2017703375.

In order to prepare the microbial consortium formulation, for fungi, malt extract broth was prepared by dissolving $19 \mathrm{~g}$ of malt extract broth powder in $400 \mathrm{ml}$ of distilled water. For bacteria, a volume of $400 \mathrm{ml}$ nutrient broth was prepared by dissolving $3.2 \mathrm{~g}$ of nutrient broth powder in $400 \mathrm{ml}$ distilled water. The fermentation media were sterilised by autoclaving at $121^{\circ} \mathrm{C}$ for $20 \mathrm{~min}$ before inoculating the individual microbes. After inoculation, the broths containing inoculum were incubated in an INNOVA44 incubator shaker at a speed of $170 \mathrm{rpm}$ at $30^{\circ} \mathrm{C}$ for a period of three days to produce fermented products. The different individual fermented microbes were pooled together on the basis of synergistic behaviour.

\section{Nursery Trial}

The experiment was conducted at a commercial nursery in Johor, Malaysia. The soil type used in polybag was clay loam. Three months old oil palm seedlings were fertilised with biofertiliser with zero chemical (BF0), biofertiliser containing two different percentage rates of $\mathrm{CF}(60 \% \mathrm{BF}+40 \% \mathrm{CF}$ and $50 \% \mathrm{BF}$ $+50 \% \mathrm{CF}$ ) and two controls consisting of $100 \% \mathrm{CF}$ (CF100) with ratio of 12:12:17:2 (N: P: K: Mg) and SO medium in the form of unsieved premium compost. The five treatments were carried out in replicates of eight for every harvest. Therefore, a total of 40 experimental units were tested in this research for one harvest. The oil palm seedlings were provided by the Malaysian Palm Oil Board, Kluang, Johor.

\section{Vegetative Measurements}

Vegetative measurements for each replicate of OPS were recorded after three and five months of fertiliser application which means that the age of the OPS were six and eight months old, respectively. The 
measurements taken were plant height, meristem diameter, and number of fronds.

\section{Foliar Analysis}

At the age of six and eight months, leaflets of OPS were dried and then ground. Fifty milligrams of dried leaf powder were weighed into each crucible. The samples were then subjected to total nitrogen (N) analysis with Primacs SNC analyser (Skalar, UK). For analyses of other nutrients such as boron (B), magnesium $(\mathrm{Mg})$, phosphorus $(\mathrm{P})$, potassium $(\mathrm{K})$, calcium $(\mathrm{Ca})$, manganese $(\mathrm{Mn})$, iron $(\mathrm{Fe})$, copper $(\mathrm{Cu})$, zinc $(\mathrm{Zn})$, and molybdenum $(\mathrm{Mo})$, the samples were first digested using a Microwave Oven (Memmert, Germany) according to the US EPA Test Method 3050B (Kimbrough and Wakakuwa, 1989). The digested samples were filtered using filter paper and diluted with MilliQ water prior to analysis using ICP Mass Spectrometer ELAN DRC (Perkin Elmer SCIEX, USA).

\section{Statistical Analysis}

Results of the nutrient analyses were analysed statistically using IBM SPSS Statistics software. All the data were reported as means \pm SE (standard error). The mean for each treatment for the respective analysis was separated statistically using Duncan's test as we wanted to test the differences among mean values of every treatment at $p<0.05$ level of significance.

\section{RESULTS AND DISCUSSION}

Biofertilisers amended with inorganic fertiliser are used to increase nutrient availability to plant and can also affect the soil microbial biodiversity (Javoreková et al., 2015). Generally, the microbial consortium includes plant growth promoting rhizobacteria, nitrogen fixing bacteria, plant disease suppressive bacteria and fungi, soil toxicant degrading microbes, actinomycetes which are important for soil health, plant growth and yield as well as to increase soil microbial diversity (Haque et al., 2011; Egamberdiyeva, 2007). Microbes from the genus Bacillus are the most commonly used as they always dominate in the rhizosphere (Morgan et al., 2005). While microbes belonging to the genus Trichoderma have also been described to be beneficial for host plants as they are involved in a complex mechanism to also promote plant growth, development and protection (Nihorimbere et al., 2011).

The vegetative measurements of OPS at six and eight months old are shown in Table 1. For both harvests, the plant height of OPS treated with BF $+50 \%$ CF were the highest at $37.75 \mathrm{~cm}$ and 64.75 $\mathrm{cm}$, respectively. This shows that application of biofertiliser integrated with CF can increase height of OPS. Mekki (2016) also found that application of biofertiliser in combination with $\mathrm{CF}$ enhanced the growth and yield of plant. Similar observation was made on the number of fronds; the application of BF $+50 \%$ CF has led to the highest number of leaves for six (5.38) and eight months old (10.50) of OPS (Table 1). Meanwhile, the meristem diameters of OPS at the age of six months were comparable between all treatments ranging between $10.55-13.13 \mathrm{~cm}$. However, at the age of eight months, the oil palm seedlings treated with $\mathrm{BF}+50 \% \mathrm{CF}$ were the highest at $34.00 \mathrm{~cm}$ and was significantly higher than CF100 $(11.66 \mathrm{~cm})$ and SO $(2.33 \mathrm{~cm})$. The effects of biofertilisers on growth of the seedlings were due to the plant growth-promoting microbes contained in the biofertiliser which are responsible for enhancing plant growth and protect them from diseases (Dimkpa et al., 2009). For example, P-solubilising bacteria improved nutrients availability by increasing nitrogenase activity which resulted in better growth of OPS (Dadresan et al., 2015).

Apart from that, significant improvements on the meristem diameter was aided by the microbes attaching to the roots and colonising the root surfaces efficiently and stimulated the development and health of the plants (Hayat et al., 2010; Vacheron et al., 2013; Van Der Heijden et al., 2008). In addition,

TABLE 1. VEGETATIVE MEASUREMENT FOR OIL PALM SEEDLINGS TREATED WITH BIOFERTILISER CONTAINING DIFFERENT PERCENTAGE RATES OF CHEMICAL FERTILISER, $100 \%$ CHEMICAL AND STANDARD ORGANIC FERTILISER

\begin{tabular}{|c|c|c|c|c|c|c|}
\hline \multirow[t]{2}{*}{ Treatment } & \multicolumn{3}{|c|}{ Six MOOS } & \multicolumn{3}{|c|}{ Eight MOOS } \\
\hline & $\mathrm{Ph}(\mathrm{cm})$ & $\operatorname{Md}(\mathrm{cm})$ & NOF & $\mathrm{Ph}(\mathrm{cm})$ & Md (cm) & NOF \\
\hline BF0 & $35.75 \pm 0.98^{b}$ & $12.75 \pm 0.59^{a}$ & $5.25 \pm 0.25^{\mathrm{a}}$ & $61.63 \pm 3.55^{\mathrm{b}}$ & $31.25 \pm 1.13^{c}$ & $10.50 \pm 0.50^{b}$ \\
\hline $\mathrm{BF}+40 \% \mathrm{CF}$ & $12.38 \pm 0.65^{\mathrm{a}}$ & $13 \pm 0.80^{\mathrm{a}}$ & $5.00 \pm 0.33^{\mathrm{ab}}$ & $56.50 \pm 2.34^{\mathrm{ab}}$ & $30.88 \pm 1.48^{c}$ & $10.38 \pm 0.46^{b}$ \\
\hline $\mathrm{BF}+50 \% \mathrm{CF}$ & $37.75 \pm 2.21^{\mathrm{b}}$ & $13.125 \pm 0.58^{\mathrm{a}}$ & $5.38 \pm 0.26^{b}$ & $64.75 \pm 2.35^{\mathrm{b}}$ & $34.00 \pm 2.97^{c}$ & $10.50 \pm 0.73^{b}$ \\
\hline CF100 & $13.19 \pm 0.38^{a}$ & $10.55 \pm 1.45^{\mathrm{a}}$ & $4.63 \pm 0.26^{\mathrm{ab}}$ & $59.13 \pm 1.65^{b}$ & $11.66 \pm 4.40^{\mathrm{b}}$ & $8.13 \pm 0.30^{a}$ \\
\hline $\mathrm{SO}$ & $13.25 \pm 0.88^{a}$ & $12.38 \pm 0.75^{\mathrm{a}}$ & $4.25 \pm 0.16^{\mathrm{a}}$ & $49.38 \pm 3.82^{\mathrm{a}}$ & $2.33 \pm 0.26^{\mathrm{a}}$ & $8.13 \pm 0.40^{a}$ \\
\hline
\end{tabular}

Note: Data reported as mean and standard error for oil palm seedlings (OPS) treated with biofertiliser (BF) containing different percentage rates of chemical fertiliser (CF), 100\% chemical (CF100) and standard organic (SO) fertiliser. abcd In the same row indicated the significant different [analysis of variance (ANOVA) p<0.05]. MOOS - month oil palm seedling, Ph - plant height, Md - meristem diameter, NOF number of frond. BFO - biofertiliser with zero chemicals. 
the increase in the vegetative growth of the OPS was due to the uptake of $\mathrm{N}$ from the soil as this nutrient is responsible for chlorophyll content and it is also vital for synthesis of food material in plants (Fraile et al., 2015). It was revealed that the integration of microbial inoculants contained in biofertilisers was significant for plant height, diameter and yield production (El-Naggar, 2010). Biofertilisers are considered as an alternative to reduce the impact of chemical fertilisers in agriculture as it contain different kind of microbes which have the ability to convert nutrients from unavailable to available forms and produced plant-growth stimulating factors (Chen, 2006).

Chemical or microbial-based fertiliser has its advantages and disadvantages in terms of nutrient supply, soil quality and crop growth. Developing a biofertiliser by integration with a CF was believed to promote the nutrient uptake as it was aided by the beneficial microbes contained in the biofertiliser (Azab and El-Dewiny, 2018). Plants need adequate macronutrients and micronutrients to ensure a healthy plant growth as they are among the most important factors affecting the plant productivity. $\mathrm{N}, \mathrm{P}$, and $\mathrm{K}$ are macronutrients that play a vital role in ensuring the growth of the plant (Figures 1 and 2). Their availability in biofertilisers help the microbes to work efficiently (Miransari, 2013). The deficiency of some macronutrients will adversely affect the plant health and growth (Hirel et al., 2011). For OPS at six months old, $\mathrm{N}$ was recorded highest in the seedlings treated with biofertiliser containing 50\% CF $(2.55 \%)$ as compared to the application of CF100 and SO (1.55\% and $1.23 \%$, respectively). After five months of application, when the OPS were eight months old, $\mathrm{N}$ was increased and maintained as the highest $(3.19 \%)$ in OPS treated with biofertiliser containing $50 \%$ of CF compared to sole application of CF $(3.07 \%)$ and SO $(2.59 \%)$.

$\mathrm{P}$ is among the most important nutrient for root, seed and fruit development in plants. Sufficient uptake of $\mathrm{P}$ is vital for the development of plants (Silva and Uchida, 2000). P deficiency may lead to poor growth of the plant (Sharma et al., 2013). The application of $\mathrm{BF}+50 \% \mathrm{CF}$ had resulted in the highest $\mathrm{P}$ uptake in the soil (1287.52 mg litre $\left.\mathrm{m}^{-1}\right)$ as compared to the application of CF100 (347.88 mg litre $^{-1}$ ) and SO (362.53 mg litre $\mathrm{m}^{-1}$ ) for six months old OPS. However, for eight months old OPS, treatment with BF $+40 \%$ CF $\left(2623.88 \mathrm{mg}\right.$ litre $\left.^{-1}\right)$ indicated the highest P content compared to CF100 (624.38 mg litre $\left.^{-1}\right)$ and SO (711.80 mg litre $\left.{ }^{-1}\right)$. The higher foliar $\mathrm{P}$ content in the OPS was due to the application of biofertilisers that contain phosphate solubilising bacteria, which have the capability to solubilise inorganic phosphate compounds and liberate the organic phosphate (Oteino et al., 2015).

Macronutrient $\mathrm{K}$ is considered as one of the important nutrients to improve the growth and yield of plants. Apart from that, $\mathrm{K}$ is also an essential nutrient as it is involved in metabolic processes such as photosynthesis and transport of sugar. It is also responsible for the survival of plants under biotic and abiotic stresses (Wang et al., 2013). The deficiency of $\mathrm{K}$ may lead to the scorching effects of leaf, slow and poor development of root (Prajapati and Modi,

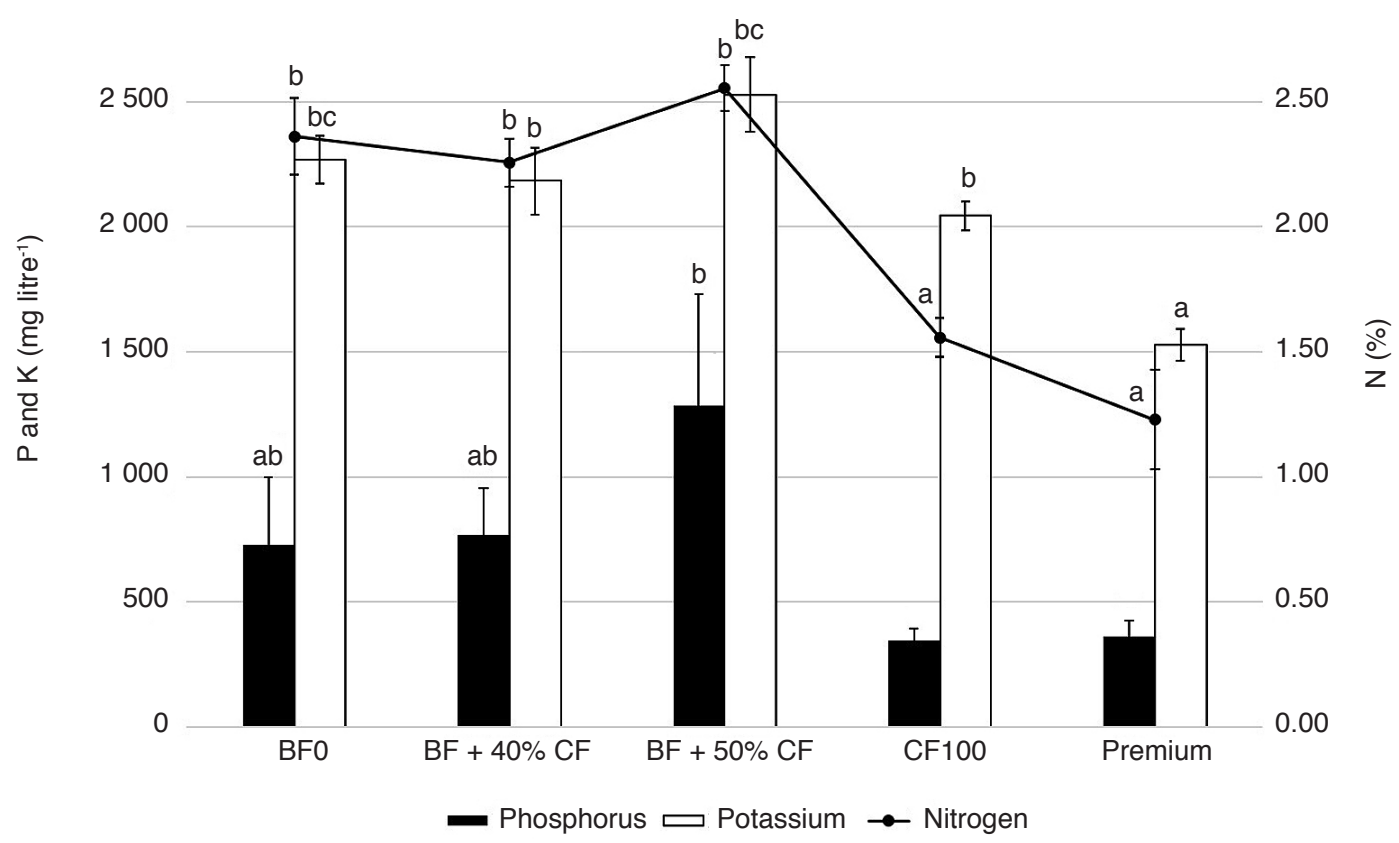

Figure 1. Nitrogen $(N)$, phosphorus $(P)$ and potassium $(K)$ content in oil palm seedlings (OPS) of six months old treated with biofertiliser (BF) containing different percentage rates of chemical fertiliser (CF), 100\% chemical (CF100) and standard organic (SO) fertiliser. 


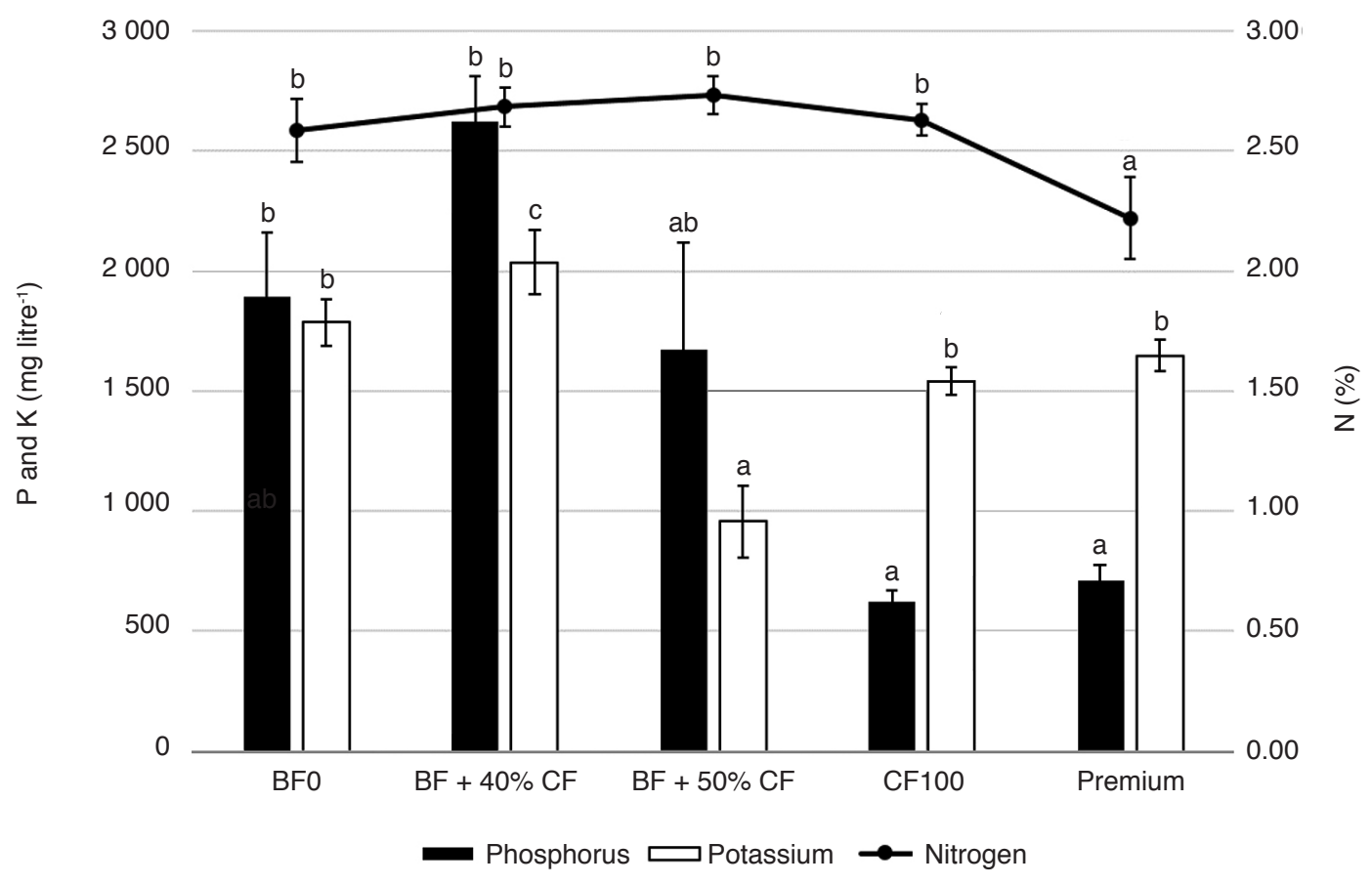

Figure 2. Nitrogen (N), phosphorus (P) and potassium (K) content in oil palm seedlings (OPS) of eight months old treated with biofertiliser (BF) containing different percentage rates of chemical fertiliser (CF), 100\% chemical (CF100) and standard organic (SO) fertiliser.

2012). Similar to $P, K$ was recorded highest in OPS of six months old which were treated with $\mathrm{BF}+50 \% \mathrm{CF}$ (2528.93 $\mathrm{mg}$ litre $\left.{ }^{-1}\right)$ compared to CF100 (2043.95 mg litre $^{-1}$ ) and SO (1528.66 mg litre $\left.\mathrm{e}^{-1}\right)$. However, at eight months old, K was significantly high in OPS treated with $\mathrm{BF}+40 \%$ CF (2037.96 mg litre ${ }^{-1}$ ). Meanwhile, the OPS treated with CF100 and SO have low K levels which were $1543.54 \mathrm{mg}$ litre $^{-1}$ and $957.833 \mathrm{mg}$ litre $^{-1}$, respectively.

Plants also need a right combination of micronutrients to live and grow (Tables 2 and 3 ). The application of biofertilisers has also increased the level of micronutrients $\mathrm{B}, \mathrm{Mg}, \mathrm{Ca}, \mathrm{Mn}, \mathrm{Fe}$, $\mathrm{Cu}, \mathrm{Zn}$ and Mo. An adequate amount of the micronutrients help to elevate biochemical and metabolic characteristics in plants (Tripathi et al., 2015). Besides that, micronutrients also resulted in the increase of the vegetative measurements of the plants. The deficiency of micronutrients will give similar symptoms to the plants such as chlorosis and yellowing of the leaves (Bradley and Hosier, 1999). $\mathrm{B}$ is among the important trace element as it helps to develop the plasma membrane and is involved in several metabolic pathways. The deficiency of B in plants would impose unhealthy effects such as yellowing of the leaf tips, chlorosis and necrotic spot and stunting the growth of the plant (Cristobal et al., 2008). In this research, the application of $\mathrm{BF}+50 \%$ CF has resulted in the highest boron content in the OPS of six months old which was $5.18 \mathrm{mg} \mathrm{litre}{ }^{-1}$ as compared to CF100, $3.54 \mathrm{mg}$ litre $^{-1}$ and SO, 3.50 mg litre ${ }^{-1}$. However, after five months of fertiliser application, B was highest in OPS treated with BF0 which was $6.14 \mathrm{mg}^{\text {litre }}{ }^{-1}$ compared to CF100 and SO which were $3.66 \mathrm{mg}$ litre $^{-1}$ and $5.17 \mathrm{mg}$ litre $^{-1}$ respectively. This result showed a promising effect in using biofertilisers rather than chemical which is harmful for the environment.

Adequate amount of $\mathrm{Mg}$ acts as a regulator of physiological processes in plants which influence their susceptibility to plant diseases. Deficiency of $\mathrm{Mg}$ could lead to the degradation of chlorophyll in leaves (Huber and Jones, 2013). Mg content in OPS after three months of fertiliser application was comparable and there was no significant difference between all treatments; whilst SO indicated slightly high $\mathrm{Mg}$ content which was 2368.92 compared to the three biofertilisers (2190.35-2323.57 $\mathrm{mg} \mathrm{litre}^{-1}$ ) and CF (2243.83 mg litre $\left.{ }^{-1}\right)$. However, after five months, $\mathrm{Mg}$ was recorded the highest in OPS treated with $\mathrm{BF}+50 \% \mathrm{CF}$ which was $4081.89 \mathrm{mg}$ litre $^{-1}$ compared to CF100 (1981.21 mg litre ${ }^{-1}$ ) and SO (3071.92 mg litre ${ }^{-1}$ ).

Higher Ca was recorded in six months old OPS, treated with BF $+50 \%$ CF (7630.68 mg litre $\left.{ }^{-1}\right)$ compared to the seedlings treated with CF100 and SO (3988.50 mg litre-1 and $4699.45 \mathrm{mg}$ litre $^{-1}$ respectively). The application of biofertiliser promoted the uptake of Ca from soil, which resulted in the increase of foliar Ca in OPS at eight months old. The highest recorded Ca was in OPS treated with $\mathrm{BF}+40 \% \mathrm{CF}$, which was 3664.83 mg litre ${ }^{-1}$, compared to seedlings treated with CF100 (2489.97 $\mathrm{mg} \mathrm{litre}^{-1}$ ) and SO (3081.95 mg litre $\left.{ }^{-1}\right)$. The increase 

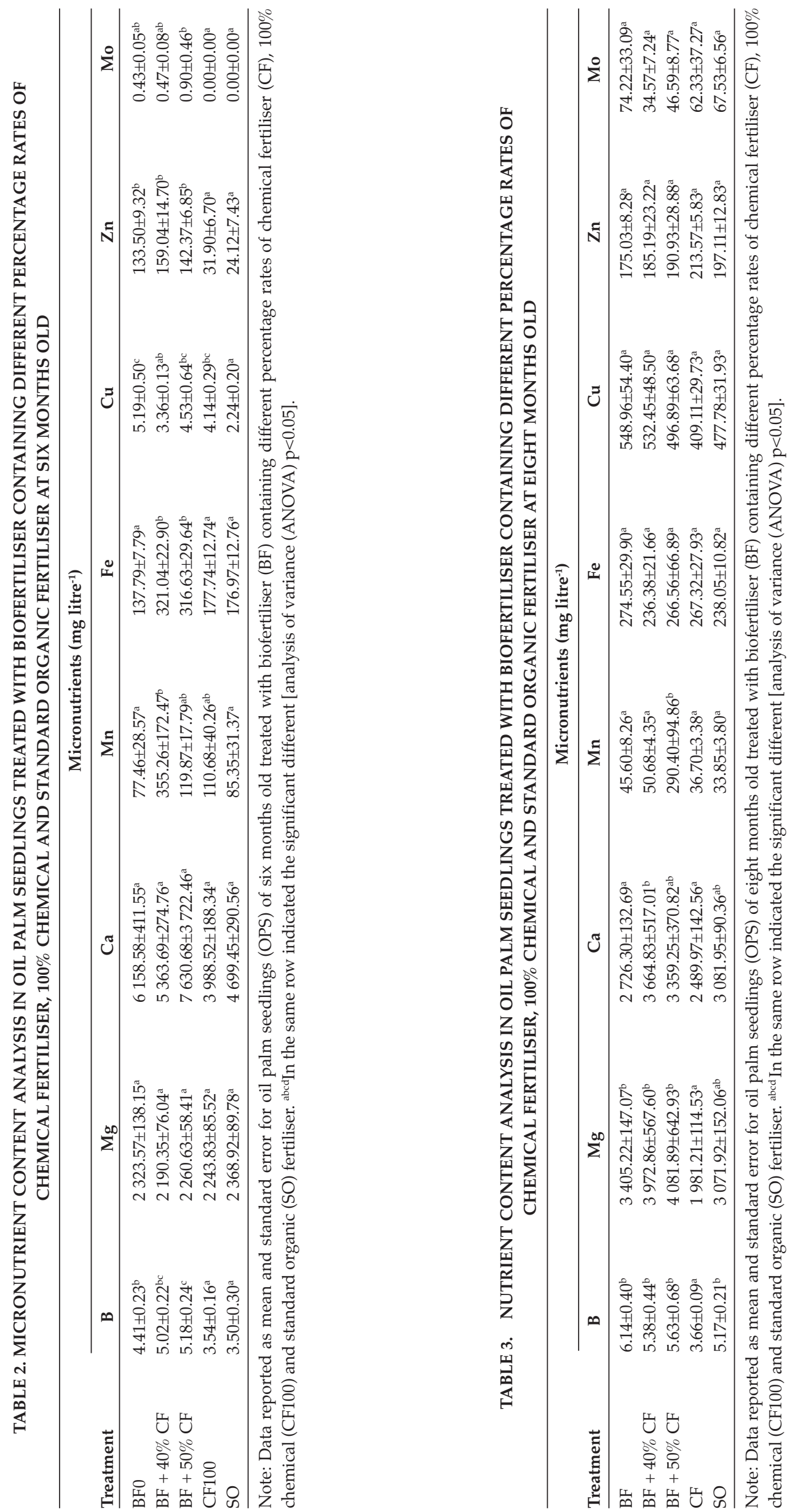
of $\mathrm{Ca}$ in OPS treated with microbe-based fertiliser explained the increase in vegetative growth of OPS as $\mathrm{Ca}$ is important to promote plant development (Hepler, 2005). Stunted plant growth, necrotic leaf margins and eventual death of terminal buds and root tips are due to the deficiency of $\mathrm{Ca}$ in plants (Stevens et al., 2002).

Similarly with $\mathrm{Mn}$, biofertiliser application also resulted in its highest content in six months old OPS treated with BF $+40 \%$ CF (355.26 mg litre $\left.{ }^{-1}\right)$ compared to CF100 (110.68 mg litre $\left.^{-1}\right)$ and SO (85.35 $\mathrm{mg}$ litre $\left.^{-1}\right)$. A significant difference of $\mathrm{Mn}$ was seen in eight months old OPS fertilised with $\mathrm{BF}+50 \% \mathrm{CF}$ (290.40 mg litre $\mathrm{m}^{-1}$ ). However, seedlings treated with CF100 and SO indicated the lowest Mn contents which were $36.70 \mathrm{mg}$ litre $^{-1}$ and $33.85 \mathrm{mg}$ litre $^{-1}$ respectively. Deficiency or excess of Mn lead to the yellowing of the leaves, premature fall of the leaf, delayed maturity, and formation of white and grey spots on leaves (Tripathi et al., 2015).

Fe is also among the important elements which are required by plants for living. The increased amount of Fe could affect the uptake of other nutrients such as $\mathrm{Ca}, \mathrm{Mg}, \mathrm{P}$, and $\mathrm{K}$. Therefore, Fe is needed in adequate amounts to avoid excess amounts which in turn creates another micronutrient deficiency (Cui et al., 2015). The application of BF $+40 \%$ CF promoted the uptake of the nutrient from the soil which has resulted in the highest foliar Fe in six months old OPS which was $321.04 \mathrm{mg}$ litre $^{-1}$, compared to application with CF100 (177.74 mg litre $^{-1}$ ) and SO (176.97 mg litre $\mathrm{m}^{-1}$ ). At eight months old, all treatments gave comparable results; with BF0 being slightly higher (274.55 mg litre-1) compared to other treatments $\left(236.38 \mathrm{mg} \mathrm{litre}^{-1}\right.$ $-267.32 \mathrm{mg}$ litre $^{-1}$ )

$\mathrm{Cu}$ is essential for promoting metabolism of plants and helps in increasing crop yield. However, excessive application might induce toxicity to the plant (Zhu et al., 2012). Inadequate amounts of $\mathrm{Cu}$ in plants adversely affect plant growth and plant photosynthesis process (Peng et al., 2013). After three months of fertilisation, $\mathrm{Cu}$ recorded highest in OPS treated with BF0 (5.19 $\mathrm{mg}$ litre $\left.^{-1}\right)$ compared to application of CF100 (4.14 mg litre $\left.{ }^{-1}\right)$ and SO (2.24 $\mathrm{mg}$ litre $\left.^{-1}\right)$. However, after five months of fertiliser application, biofertiliser managed to increase the uptake of $\mathrm{Cu}$ from the soil. $\mathrm{Cu}$ was seen comparable between all treatments which ranged between 409.11- 548.96 mg litre $^{-1}$.

Johnson (2010) stated that the microbes in biofertiliser are able to increase the $\mathrm{Zn}$ uptake from the soil. Deficiency of Zn may lead to stunted development of plants and chlorosis effect on leaves (Sharma et al., 2015). For OPS of six months old, application of $\mathrm{BF}+40 \% \mathrm{CF}$ resulted in the highest $\mathrm{Zn}$ content (159.04 mg litre ${ }^{-1}$ ) compared to application of CF100 (31.90 mg litre ${ }^{-1}$ ) and SO (24.12 mg litre $^{-1}$ ). The amount of $\mathrm{Zn}$ increased after five months of fertilisation; which was observed comparable between all treatments ranging between 175.03$213.57 \mathrm{mg}$ litre $^{-1}$.

Mo was highly significant in six months old OPS treated with all kinds of biofertiliser. Seedlings treated with $\mathrm{BF}+50 \% \mathrm{CF}$ yielded the highest Mo content $\left(0.90 \mathrm{mg}\right.$ litre $\left.^{-1}\right)$ whilst for CF100 and SO application, zero Mo was detected. For application of fertiliser after five months, BF0 which is chemicalfree indicated the highest Mo which was $74.22 \mathrm{mg}$ litre $^{-1}$ compared to sole application of chemical, CF100 (62.33 mg litre ${ }^{-1}$ ) and SO (67.53 mg litre $\mathrm{m}^{-1}$ ). It was noted that using biofertiliser can help to improve plants uptake of Mo from the soil. Mo is known to be one of the important micronutrients for plant growth and development. Its deficiency leads to the chlorosis effect of the leaves (Fageria et al., 2015).

The growth-promoting microbes contained in biofertiliser are able to regulate many enzymatic processes which consequently increase the vegetative growth of the plant. Furthermore, the utilisation of microbes in fertilisation can act as a biological control for plant pathogens, $\mathrm{N}$ fixation, and solubilisation of beneficial nutrients (Ge et al., 2016). Researchers found out that the application of biofertiliser with integration of low rates of chemical was responsible in enhancing the nutrients uptake and vegetative measurements of plants. Apart from that, Rakha and El-Said (2013) stated that the mixture of microbial consortium with inorganic fertiliser can cause the plants to receive the best nutritional values resulting in the higher content of $\mathrm{N}, \mathrm{P}, \mathrm{K}$ and other nutrients content. In addition, its application can also reduce the sole use of chemical fertilisers which are not environmental-friendly and expensive.

\section{CONCLUSION}

Compared to the sole application of $100 \%$ chemical, the application of biofertiliser containing low chemical rates significantly improved the vegetative measurements and the nutrients absorption of oil palm seedlings. The usage of microbial inoculants contained in biofertiliser helped to regulate the availability of nutrients in the soil which resulted in healthy oil palm. Adding to this, the beneficial microbes contained in the biofertiliser improved the plant quality, increased the soluble $\mathrm{P}$ content, helped in nutrients intake by the plants, and enhanced the populations of phosphate-solubilising and proteolytic bacteria. Based from our results, the application of biofertiliser with the combination of CF gave a higher quality effect on the OPS. Therefore, we conclude that the integration of environmentalfriendly biofertiliser with low rates of CF provides a promising alternative to replace the usage of $100 \%$ 
$\mathrm{CF}$, which is expensive and less friendly to the environment.

\section{ACKNOWLEDGEMENT}

The authors would like to thank the DirectorGeneral of MPOB for permission to publish this article. The authors would also like to thank Dr Siti Ramlah Ahmad Ali for the guidance throughout the project, the management of Hong Seng Nursery, Johor, Malaysia for allowing the trial to be conducted at the nursery and the staff of the Microbial Technology Engineering Centre (MICROTEC), Biology Division, MPOB for lending a hand during the research works. This research is supported by MPOB Research Fund (R010011000).

\section{REFERENCES}

Azab, M E E and El-Dewiny, C Y (2018). Effect of bio and mineral nitrogen fertiliser with different levels on growth, yield and quality of maize plants. J. Innovations in Pharmaceutical and Biological Sciences, 5(2): 70-75.

Bhardwaj, D; Ansari, M; Sahoo, R and Tuteja, N (2014). Biofertilisers function as key player in sustainable agriculture by improving soil fertility, plant tolerance and crop productivity. Microbial Cell Factories, 13(1): 66

Bradley, L and Hosier, S (1999). Guide to symptoms of plant nutrient deficiencies. The University of Arizona Cooperative Extension, 11(5): 1-3.

Chen, J (2006). The combined use of chemical and organic fertilisers and/or biofertiliser for crop growth and soil fertility. Taipei Food Fertiliser Technology Bull., 17(10): 1-11.

Cristobal, C J J; Rexach, J and Fontes, A G (2008). Boron in plants: Deficiency and toxicity. J. Integrative Plant Biology, 50(10): 1247-1255.

Cui, X D; Wang, Y J; Hockmann, K and Zhou, D M (2015). Effect of iron plaque on antimony uptake by rice (Oryza sativa L.). Environmental Pollution, 204(1995): 133-140.

Dadresan, M; Pourbabaie, A; Chaichi, M R; Hosseini, M B; Yazdani, D and Zandvakili, O R (2015). Effect of bio-fertilisers on the growth, productivity and nutrient absorption of Fenugreek (Trigonella foenum graecum L.). International J. Agriculture Innovations and Research, 3(5): 1628-1633.

Dimkpa, C; Weinand, T and Asch, F (2009). Plantrhizobacteria interactions alleviate abiotic stress conditions. Plant, Cell and Environment, 32(12): 16821694.

Egamberdiyeva, D (2007). The effect of plant growth promoting bacteria on growth and nutrient uptake of maize in two different soils. Applied Soil Ecology, 36(2-3): 184-189.

El-Naggar, A H (2010). Effect of biofertiliser, organic compost and mineral fertilisers on the growth, flowering and bulbs production of Narcissus Tazetta, L. J. Agric. E Env. Sci. Alex. Univ. Egypt, 9(1): 24-52.

Fageria, N K; Stone, L F and Santos, A B (2015). Molybdenum requirements of dry bean with and without liming. Communications in Soil Science and Plant Analysis, 46(5): 37-41.

Fraile, G P, Menendez, E and Rivas, R (2015). Role of bacterial biofertilisers in agriculture and forestry. AIMS Bioengineering, 2(3): 183-205.

Ge, C; Radnezhad, H; Abari, M F; Sadeghi, M and Kashi, G (2016). Effect of biofertilisers and plant growth promoting bacteria on the growth characteristics of the herb Asparagus officinalis. Applied Ecology and Environmental Research, 14(3): 547-558.

Gupta, A K (2004). The Complete Technology Book on Biofertilisers and Organic Farming. National Institute of Industrial Research Press, India. 608 pp.

Hadi, M; Basri, A; Abdu, A; Jusop, S; Ahmed, O H; Abdul-Hamid, H; Kusno, M; Zainal, B; Senin, A L and Junejo, N (2013). Effects of mixed organic and inorganic fertilisers application on soil properties and the growth of Kenaf (Hibiscus cannabinus L.) cultivated on Bris soils. American J. Applied Sciences, 10(12): 1586-1597.

Haque, M; Ilias, A H G N M and Molla, A H (2011). Trichoderma-enriched biofertiliser: A prospective substitute of inorganic fertiliser for mustard (Brassica campestris) production. The Agriculturists, 8(2): 66-73.

Hayat, R; Ali, S; Amara, U; Khalid, R and Ahmed, I (2010). Soil beneficial bacteria and their role in plant growth promotion: A review. Annals of Microbiology, 60(4): 579-598.

Hepler, P K (2005). Calcium: A central regulator of plant growth and development. The Plant Cell Online, 17(8): 2142-2155.

Hirel, B; Tétu, T; Lea, PJ and Dubois, F (2011). Improving nitrogen use efficiency in crops for sustainable agriculture. Sustainability, 3(9): 1452-1485. 
Huber, D M and Jones, J B (2013). The role of magnesium in plant disease. Plant and Soil, 368(1-2): 73-85.

Ibiene, A; Agogbua, J; Okonko, I and Nwachi, G (2012). Plant growth promoting rhizobacteria (PGPR) as biofertiliser: Effect on growth of Lycopersicum esculentus. J. American Science, 88(22): 318-324.

Javoreková, S; Maková, J; Medo, J and Kovácsová, $S$ (2015). Effect of bio-fertilisers application on microbial diversity and physiological profiling of microorganisms in arable soil. Eurasian J. Soil Science, 4: 54-61.

Johnson, N C (2010). Tansley review resource stoichiometry elucidates the structure and function of arbuscular mycorrhizas across scales. New Phytologist, 185(3): 631-647.

Kimbrough, D E and Wakakuwa, J R (1989). Acid digestion for sediments, sludges, soils, and solid wastes. A proposed alternative to EPA SW 846 Method 3050. Environmental Science \& Technology, 23(7): 898-900.

Mekki, B E (2016). Effect of bio-organic, chemical fertilisers and their combination on growth, yield and some macro and micronutrients contents of faba bean (Vicia faba L.). Bioscience Research, 13(1): 8-14.

Miransari, M (2013). Soil microbes and the availability of soil nutrients. Acta Physiologiae Plantarum, 35(11): 3075-3084.

Mishra, D; Rajvir, S; Mishra, U and Kumar, S (2013). Role of bio-fertiliser in organic agriculture: A review. Research J. Recent Sciences, 2(27): 39-41.

Mohammadi, K and Sohrabi, Y (2012). Bacterial biofertilisers for sustainable crop production: A review. J. Agricultural and Biological Science, 7(5): 307316.

Mondal, T; Datta, J K and Mondal, N K (2015). Chemical fertiliser in conjunction with biofertiliser and vermicompost induced changes in morphophysiological and bio-chemical traits of mustard crop. J. Saudi Society of Agricultural Sciences, 16(2): 135-144.

Morgan, J A W; Bending, G D and White, P J (2005). Biological costs and benefits to plant - Microbe interactions in the rhizosphere. J. Experimental Botany, 56(417): 1729-1739.

Munda, S; Shivakumar, B G; Gangaiah, B; Manjaiah, K M; Rana, D S; Layek, J and Koneru, L (2015). Influence of direct and residual phosphorus fertilisation on growth and yield of potato in a soybean-potato cropping system. Australian J. Crop Science, 9(3): 191-202.

Nihorimbere, V; Ongena, M; Smargiassi, M and Thonart, P (2011). Beneficial effect of the rhizosphere microbial community for plant growth and health. Biotechnologi, Agronomy, Society and Environment, 15(2): 327-337.

Oteino, N; Lally, R D; Kiwanuka, S; Lloyd, A; Ryan, D; Germaine, K J and Dowling, D N (2015). Plant growth promotion induced by phosphate solubilizing endophytic Pseudomonas isolates. Frontiers in Microbiology, 6(7): 1-9.

Peng, H; Kroneck, P M H and Küpper, H (2013). Toxicity and deficiency of copper in Elsholtzia splendens affect photosynthesis biophysics, pigments and metal accumulation. Environmental Science and Technology, 5(10): 1-32.

Prajapati, K and Modi, H A (2012). The importance of potassium in plant growth - A review. Indian J. Plant Sciences, 1(2-3): 177-186.

Rakha, M K A and El-Said, E S M (2013). Growth and yield of broad bean (Vicia faba L.) as affected by chemical and/or natural phosphorus with different biofertiliser. J. Plant Production, 4(12): 1857-1869.

Savci, S (2012). An agricultural pollutant: Chemical fertiliser. International J. Environmental Science and Development, 3(1): 11-14.

Sharma, A; Patni, B and Shankhdhar, D (2015). Zinc - An indispensable micronutrient. Physiology Molecular Biology Plants, 19(2013): 11-20.

Sharma, S B; Sayyed, R Z; Trivedi, M H and Gobi, T A (2013). Phosphate solubilizing microbes: Sustainable approach for managing phosphorus deficiency in agricultural soils. SpringerPlus, 2(1): 587.

Silva, J and Uchida, R (2000). Essential nutrients for plant growth: Nutrients functions and deficiency symptons. Plant Nutrient Management in Hawaii's Soils, Approaches for Tropical and Subtropical Agriculture. University of Hawaii, Honolulu, Hawaii, USA. p. 31-55.

Stevens, G; Motavalli, P; Scharf, P; Nathan, M and Dunn, D A (2002). Crop Nutrient Deficiencies and Toxicities. University of Missouri-Columbia Extension Publications, USA. p. 1-18.

Tripathi, D K; Singh, S; Singh, S; Mishra, S; Chauhan, D K and Dubey, N K (2015). Micronutrients and 
their diverse role in agricultural crops: Advances and future prospective. Acta Physiologiae Plantarum, 37(7): 2-14.

Vacheron, J; Desbrosses, G; Bouffaud, M L; Touraine, B; Moënne-Loccoz, Y; Muller, D; Legendre, L; Dye, F W and Combaret, CP (2013). Plant growth-promoting rhizobacteria and root system functioning. Frontiers in Plant Science, 4(9): 1-19.

Van der Heijden, M G A; Bardgett, R D and Van Straalen, N M (2008). The unseen majority: Soil microbes as drivers of plant diversity and productivity in terrestrial ecosystems. Ecology Letters, 11(3): 296-310.

Wang, M; Zheng, Q; Shen, Q and Guo, S (2013). The critical role of potassium in plant stress response. International J. Molecular Sciences, 4: 7370-7390.
Zahir, Z A; Shah, M K; Naveed, M and Akhter, M J (2010). Substrate-dependent auxin production by Rhizobium phaseoli improves the growth and yield of Vigna radiata L. under salt stress conditions. J. Microbiology and Biotechnology, 20(9): 1288-1294.

Zhao, J; Ni, T; Li, J; Lu, Q; Fang, Z; Huang, Q; Zhang, R; Li, R; Shen, B and Shen, Q (2016). Effects of organic-inorganic compound fertiliser with reduced chemical fertiliser application on crop yields, soil biological activity and bacterial community structure in a rice-wheat cropping system. Applied Soil Ecology, 99: 1-12.

Zhu, Q; Zhang, M and Ma, Q (2012). Scientia horticulturae copper-based foliar fertiliser and controlled release urea improved soil chemical properties, plant growth and yield of tomato. Scientia Horticulturae, 143: 109-114. 